\title{
An experimental study on synthesis of $\beta$-Sialon composites using fly ash and lignite char-preparation and whiskers formation
}

\author{
Huan ZHAO, Pingyang WANG, Jianglong YU, ${ }^{* * *, \dagger}$ Jing ZHANG, \\ Arash TAHMASEBI* and Fanrui MENG* \\ Thermal Energy Research Centre, Shenyang Aerospace University, Shenyang 110136, PR China \\ *Key Laboratory of Advanced Coal and Coking Technology of Liaoning Province, School of Chemical Engineering, \\ University of Science and Technology Liaoning, Anshan 114051, PR China \\ ${ }^{* *}$ Chemical Engineering, University of Newcastle, Callaghan, NSW 2308, Australia
}

\begin{abstract}
$\beta$-Sialon based composites were produced using a vertical reactor by carbothermal reduction reaction under nitrogen using fly ash and lignite chars to examine the effects of mixing, carbon content, reaction temperature and sintering time. The influences of chars as a reductant were further investigated in comparison with graphite. The evolution of phase and morphology in samples were analyzed by X-ray diffraction (XRD) and scanning electron microscope (SEM). Mechanical stirring was favored to mix fly ash and chars, while ball-milling shove the chars with porous structure due to collisions of agate balls, preventing $\mathbf{N}_{2}$ penetration to the inner parts of reactants. When excess carbon was increased to $100 \%$, a higher combustion reactivity of low-temperature chars resulted in the production of $\mathrm{SiC}$ phase. The evolution of $\beta$-Sialon with increasing reaction temperature showed the samples mixed with chars were more sensitive to reaction temperature than that with graphite. $\beta$-Sialon phase increased gradually with increasing sintering time to $6 \mathrm{~h}$ and decreased thereafter due to the decomposition or conversion of $\beta$-Sialon. These changes were more significantly for samples adding lignite chars. The optimal operation has been determined and rod-like $\beta$-Sialon whiskers with high aspect ratio appeared after performing the operation. In the growth process of whiskers, bead-shape whiskers were observed, suggesting that the growth mechanism was different from the conventional vapor-liquid-solid (VLS) mechanism.
\end{abstract}

(C2015 The Ceramic Society of Japan. All rights reserved.

Key-words : $\beta$-sialon, Fly ash, Lignite char, Whisker, Carbothermal reduction reaction

[Received December 19, 2014; Accepted April 16, 2015]

\section{Introduction}

$\beta$-Sialon $\left(\mathrm{Si}_{6-\mathrm{z}} \mathrm{Al}_{\mathrm{z}} \mathrm{O}_{\mathrm{z}} \mathrm{N}_{8-\mathrm{z}}, 0<\mathrm{z} \leq 4.2\right)$ is a solid solution of $\beta-\mathrm{Si}_{3} \mathrm{~N}_{4}$ with $\mathrm{Si}-\mathrm{N}$ bonds partially substituted by $\mathrm{Al}-\mathrm{N}$ and $\mathrm{Al}-\mathrm{O}$ bonds. ${ }^{1,2)}$ This sialon based composite has attracted great interest in the scientific community and industry because of their excellent properties: high strength, high toughness and chemical inertness at high temperature. ${ }^{3), 4)}$ In order to reduce the cost-price of $\beta$-Sialon product, investigations have been performed ${ }^{5)-11)}$ to synthesis the material by sintering at high temperature and pressure, starting from natural products (pyrophyllite, zeolite, clay, bauxite, coal gangue, schist, etc.) instead of relatively expensive synthetic powders such as $\beta$ - $\mathrm{Si}_{3} \mathrm{~N}_{4}, \mathrm{AlN}, \mathrm{Si}_{2} \mathrm{~N}_{2} \mathrm{O}, \mathrm{Al}_{2} \mathrm{ON}, \mathrm{SiO}_{2}, \mathrm{Al}_{2} \mathrm{O}_{3}, \mathrm{Si}$, and Al. Fly ash, a solid by-product from coal-fired power plants, is a great potential raw material for the low-cost synthesis of $\beta$ Sialon. ${ }^{12)}$ This is of crucial importance to developing countries, such as China. The present accumulating amount of fly ash in China will reach three billion tons until 2020. ${ }^{13)}$ Approximately half of the fly ash generated has been used in cement and concrete manufacture (buildings, roads, etc.), ${ }^{4)}$ but large amounts of the ash is still waste, which causes serious environmental problems. The preparation of $\beta$-Sialon based composite with excellent mechanical properties from the waste fly ash is therefore very attractive, which diminish the fabrication cost, and provide a green channel for high value-added utilization of the ash.

Corresponding author: J. Yu; E-mail: jianglong.yu@newcastle. edu.au
Fly ashes are by-products of coal combustion in coal-fired power plants. ${ }^{4), 14)}$ These fly ashes are powders with a small particle size $(<20 \mu \mathrm{m})$, and the chemical composition is similar to clay with a total amount of $\mathrm{SiO}_{2}$ and $\mathrm{Al}_{2} \mathrm{O}_{3}$ reaching 70-90 wt $\% .{ }^{15), 16)}$ Based on their properties, recent works ${ }^{4), 12), 13), 15)-20)}$ have shown that $\beta$-Sialon can be produced from fly ash. Gilbert and Mosset ${ }^{4}$ ) obtained nearly pure $\beta$-Sialon by heating high-C fly ashes without any special preparation such as carbon addition or grinding at $1500^{\circ} \mathrm{C}$ for $1 \mathrm{~h}$. The as-formed sample appears to have submicron-size crystallites that have already begun to sinter, generating cauliflower-like structures. Shveikin and Timoshchuk $^{19)}$ used fly ash materials to synthesis $\beta$-Sialon phases with compositions $\mathrm{Si}_{3} \mathrm{Al}_{3} \mathrm{O}_{3} \mathrm{~N}_{5}$ and $\mathrm{Si}_{2} \mathrm{Al}_{3} \mathrm{O}_{7} \mathrm{~N}$ by carbothemal reduction nitridation $(\mathrm{CRN})$ process. The ash was mixed with acetylene black or Ekibastuz coal as reducer by grinding in a hard-alloy mill for $30 \mathrm{~min}$. Kudyba-Jansen et al. ${ }^{18)}$ made $\alpha$ - and $\beta$-Sialon by sintering fly ash from various sources. The stoichiometric amount of pure carbon necessary for full conversion to sialon was added to the ash. A horizontal tube furnace was used to perform the carbothermal synthesis at temperatures between 1400 and $1500^{\circ} \mathrm{C}$ for various residence times using a nitrogen flow rate of $35 \mathrm{~L} / \mathrm{h}(583.3 \mathrm{~mL} / \mathrm{min})$. Both $\beta$ Sialon as well as $\alpha / \beta$-Sialon composites could be obtained depending on the reaction time, the CRN temperature, and the overall composition of the fly ash. Ma et al. ${ }^{13)}$ synthesised $\beta$ Sialon based composites at $1723 \mathrm{~K}$ for $6 \mathrm{~h}$ while heating the sample with mass ratio of carbon black to fly ash of 0.56 . They claimed that increasing heating temperature or mass ration of 
carbon black to fly ash could promote the formation of $\beta$-Sialon. Qiu et al. ${ }^{12)}$ also added carbon black as a reduction reagent for nitridation reaction using an efficient mixing procedure (dry attrition milling). The $\mathrm{CRN}$ reactions were performed in a horizontal tube furnace equipped with a molybdenum sheet as the heating element, and characterized quantitatively by measuring the nitrogen content in the final product and the weight loss on nitridation. They identified the following conditions in the experimental setup: $T \approx 1300^{\circ} \mathrm{C}$, carbon content $[\mathrm{C}] \approx 28 \mathrm{wt} \%$, linear velocity of nitrogen gas $U \approx 45 \mathrm{~cm} / \mathrm{min}$, and reaction time $t \approx 60 \mathrm{~min}$ to obtain an almost pure $\beta$-Sialon.

In this study, the optimal production conditions of $\beta$-Sialon based composite from fly ash were investigated by carbothermal reaction under nitrogen atmosphere. Chars from low-temperature pyrolysis of lignite were used as the reductant for the nitridation reaction in comparison with graphite. The aim of this paper is to explore the effects of chars on the formation of $\beta$-Sialon from fly ash.

\section{Experimental Section}

\subsection{Materials}

Fly ash from Anshan coal-fired power plant (Liaoning, China) was used in this study. The compositions of the fly ash sample were analyzed using an X-ray Fluorescence (XRF) spectrometer and are shown in Table 1. The majority of the iron oxides in fly ash were removed by the treatment with the magnetic column to avoid the negative effect of magnetism on the mechanical properties of the sintered materials. ${ }^{18), 21)}$ X-ray diffraction (XRD) and scanning electron microscope (SEM) analysis (Fig. 1) showed that the fly ash consisted of fine particles and its crystalline phases were mainly mullite $\left(3 \mathrm{Al}_{2} \mathrm{O}_{3} \cdot 2 \mathrm{SiO}_{2}\right)$, quartz $\left(\mathrm{SiO}_{2}\right)$ and small amounts of corundum $\left(\mathrm{Al}_{2} \mathrm{O}_{3}\right)$.

The carbon content in the fly ash, $[\mathrm{C}] \approx 5.87 \mathrm{wt} \%$, is not enough for the carbothermal reduction reaction. ${ }^{12)}$ Thus, low-

Table 1. Chemical Analysis of Anshan Fly Ash Samples

\begin{tabular}{lrll}
\hline oxide & wt $\%$ & oxide & wt $\%$ \\
\hline $\mathrm{Al}_{2} \mathrm{O}_{3}$ & 20.81 & $\mathrm{MgO}$ & 1.96 \\
$\mathrm{SiO}_{2}$ & 61.79 & $\mathrm{~K}_{2} \mathrm{O}$ & 2.65 \\
$\mathrm{Fe}_{2} \mathrm{O}_{3}$ & 4.19 & $\mathrm{Na}_{2} \mathrm{O}$ & 1.2 \\
$\mathrm{CaO}$ & 2.68 & $\mathrm{SO}_{3}$ & 0.29 \\
$\mathrm{LOI}^{\text {a) }}$ & 5.87 & & \\
\hline
\end{tabular}

a) LOI: loss of ignition after $2 \mathrm{~h}$ at $815^{\circ} \mathrm{C}$ in air.

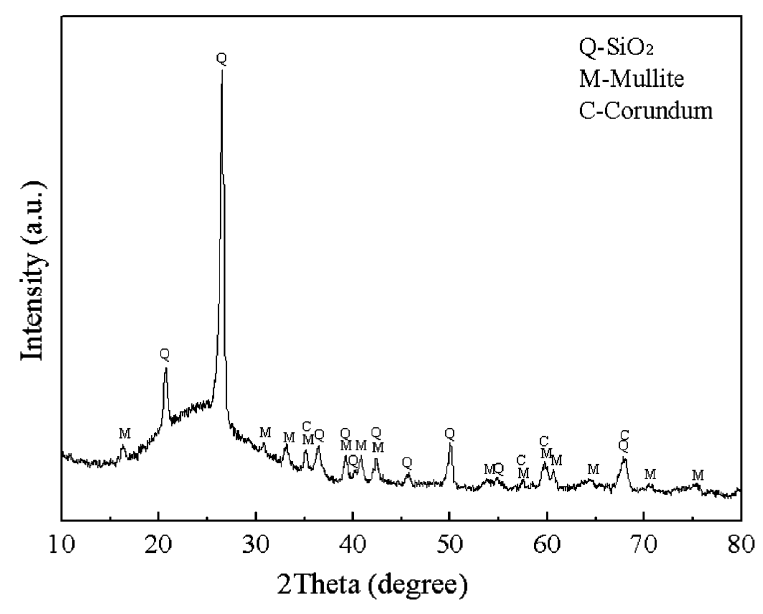

Fig. 1. XRD pattern and SEM image of the fly ash. temperature pyrolysis chars and graphite were added as the reductant for the nitridation reaction. The chars were produced from Indonesian lignite (supplied by Banpu Public Company, Ltd., Thailand) by a low-temperature pyrolysis at $400^{\circ} \mathrm{C}$ for $30 \mathrm{~min}$. The details of the experimental apparatus have been reported elsewhere. ${ }^{22)}$ The particle size distributions of the three materials in Fig. 2 revealed that more than $50 \mathrm{wt} \%$ particles were in the range from 2 to $16 \mu \mathrm{m}$.

\section{$2.2 \beta$-Sialon synthesis and characterisation}

The reaction for synthesizing $\beta$-Sialon powders is given in following equation. ${ }^{8), 12), 13 \text { ) }}$

$$
\begin{aligned}
& 3 \mathrm{Al}_{2} \mathrm{O}_{3} \cdot 2 \mathrm{SiO}_{2}(\mathrm{~s})+4 \mathrm{SiO}_{2}(\mathrm{~s})+15 \mathrm{C}(\mathrm{s})+5 \mathrm{~N}_{2}(\mathrm{~g}) \\
& \quad=2 \mathrm{Si}_{3} \mathrm{Al}_{3} \mathrm{O}_{3} \mathrm{~N}_{5}(\mathrm{~s})+15 \mathrm{CO}(\mathrm{g})
\end{aligned}
$$

The most common reductant is carbon, which eliminates the appropriate amount of oxygen, while the reduced oxides are then nitrided in the nitrogen flow. ${ }^{19)}$ The best amount of carbon addition is stoichiometric if the reactants are pure materials, e.g., silica and alumina [see reaction (1)]. ${ }^{12), 23)}$ However, for natural aluminosilicate materials (e.g., fly ash), some of excess carbon is necessary to compensate for the impurities in the carbon and nitrogen. ${ }^{24)}$ According to reaction (1), the stoichiometric mass ratio of carbon to fly ash was about 0.12 . Lignite chars or graphites, which were equal to the mass of 10,50 , and $100 \%$ excess carbon, were added to the present fly ash, respectively. The mixing of the starting materials requires an efficient mixing procedure, because the fly ash is a very fluffy power. ${ }^{12)}$ Two kinds of mixing procedures, mechanical stirring in demineralised water and ball-milling in anhydrous alcohol, were used in the present experiments. Agate balls $\left(5\right.$ and $10 \mathrm{~mm}, 94 \% \mathrm{SiO}_{2}, 6 \%$ $\mathrm{MgO} / \mathrm{CaO} / \mathrm{Mn}_{2} \mathrm{O}_{3}$ ) were used as milling media. The weight ration of balls to power was $5 / 1$. The mixing operations were performed for $4 \mathrm{~h}$, and then the mixture was pelletized into spherical particles with $5 \mathrm{~mm}$ in diameter. Subsequently the water and anhydrous alcohol were removed by drying at $110^{\circ} \mathrm{C}$.

The CRN reaction was carried out in a vertical tubular furnace $\left(\mathrm{D}=5 \mathrm{~cm}\right.$, length $20 \mathrm{~cm}$ ) between 1400 and $1450^{\circ} \mathrm{C}$ for various times using a nitrogen flow rate of $1.0 \mathrm{~L} / \mathrm{min}$. The experimental setup is shown in Fig. 3. The furnace was equipped with silicon molybdenum rods as the heating element. The pellet samples were placed in the bottom of corundum reactor, and heated in the tubular furnace. The nitrogen gas (purity 99.99\%) was introduced using the gas inlet tube through the spherical samples, and then elicited from corundum porous cover with $6 \mathrm{~mm}$ pores.

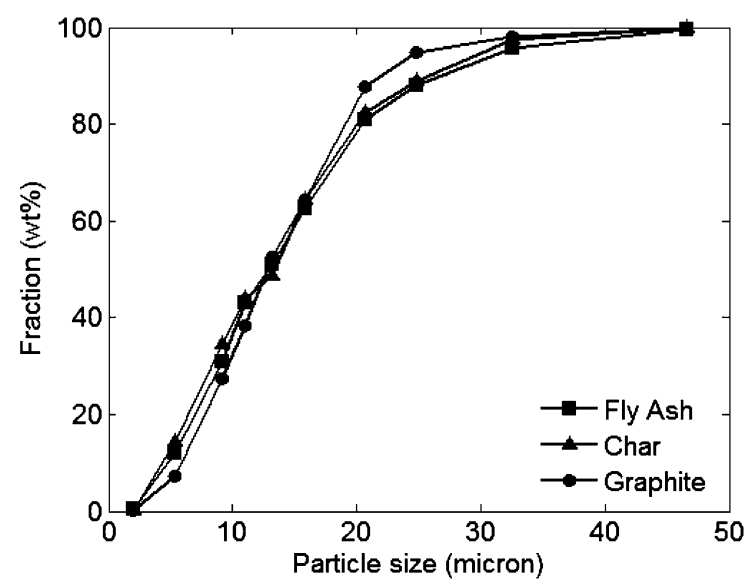

Fig. 2. Particle size distribution of the fly ash, char and graphite. 


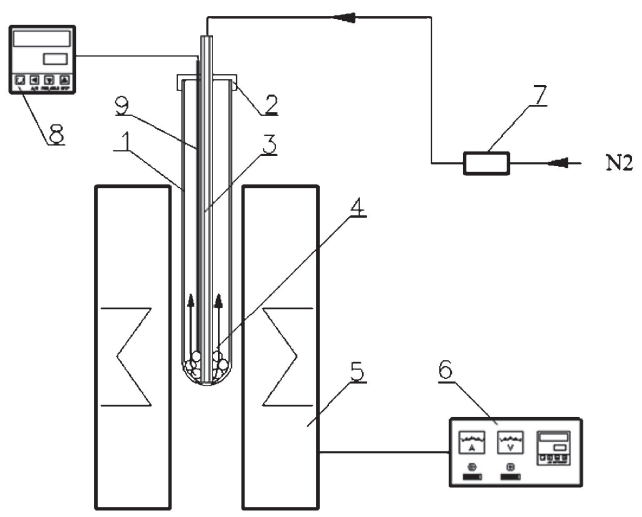

Fig. 3. Schematic diagram of experimental setup for synthesis of $\beta$-Sialons. 1-corundum reactor; 2-corundum cover; $3-\mathrm{N}_{2}$ gas inlet tube; 4-spherical samples; 5 -electric furnace; 6-furnace temperature controller; 7-mass flow controller; 8-temperature indicator and 9-thermocouple.

The phase's evolution of final products synthesized under different preparing conditions were determined by XRD (M21XSRA, MAC Science Co. Ltd., Yokohama, Japan), scanning from 10 to $80^{\circ}(2 \theta)$ using $\mathrm{Cu} \mathrm{K} \alpha$ radiation with a step of $0.02^{\circ} / \mathrm{s}$ and a rate of $2^{\circ} / \mathrm{min}$. Scanning electron microscopy (ZJIESS CSM 950, Carl Zeiss Co., Oberkochen, Germany) was used to analyze the morphology and microstructure of these products.

\section{Results and discussions}

\subsection{Optimization of $\beta$-Sialon preparation \\ 3.1.1 Effects of mixing methods}

Fly ash was mixed with lignite chars or graphite by ballmilling or mechanical stirring, and sintered at $1420^{\circ} \mathrm{C}$ for $6 \mathrm{~h}$. The results are shown in Fig. 4. The comparison of compositions revealed that effect of mixing methods on the formation of $\beta$ Sialon phase was substantial. In the case of samples mixed with char, the diffraction intensities of $\beta$-Sialon for the samples mixed by ball-milling were significantly lower than that mixed by mechanical stirring. However, this difference was not obvious for samples with graphite, implying that the surface chemistry of carbon materials may have been changed during ball-milling in the case of char. The collisions of agate balls during mixing process possibly shove carbon materials, although mixing procedure can improves the contact between fly ash and the added carbon and can thus significantly increase the reactivity of the reactants. ${ }^{12)}$ Figure 5 shows that the morphology of char and graphite before the mixing operation. Many macropores and vesicles were observed on the char surface because of the release of volatile matter during the pyrolysis of lignite. The graphite just showed a flaky structure without pores. The lower diffraction intensities of $\beta$-Sialon for samples mixed with char by ballmilling compared to that with graphite implied that the structure changes during ball-milling has led to the decrease of the reactivity of chars during carbothermal reduction reactions. For the sample mixed with char by mechanical stirring, the diffraction intensities of $\beta$-Sialon phase prepared under the present conditions was the strongest, indicating the sufficient reaction between fly ash and carbon in $\mathrm{N}_{2}$ gas atmosphere. It is suggested that mechanical stirring is more applicable to the preparation of $\beta$ Sialon with fly ash and lignite char.

As shown in Fig. 4, small amount of iron silicides (e.g., $\mathrm{Fe}_{3} \mathrm{Si}$ and $\mathrm{Fe}_{5} \mathrm{Si}_{3}$ ) were formed due to the reaction of the iron oxides with silica. These iron oxides were originally present in the fly
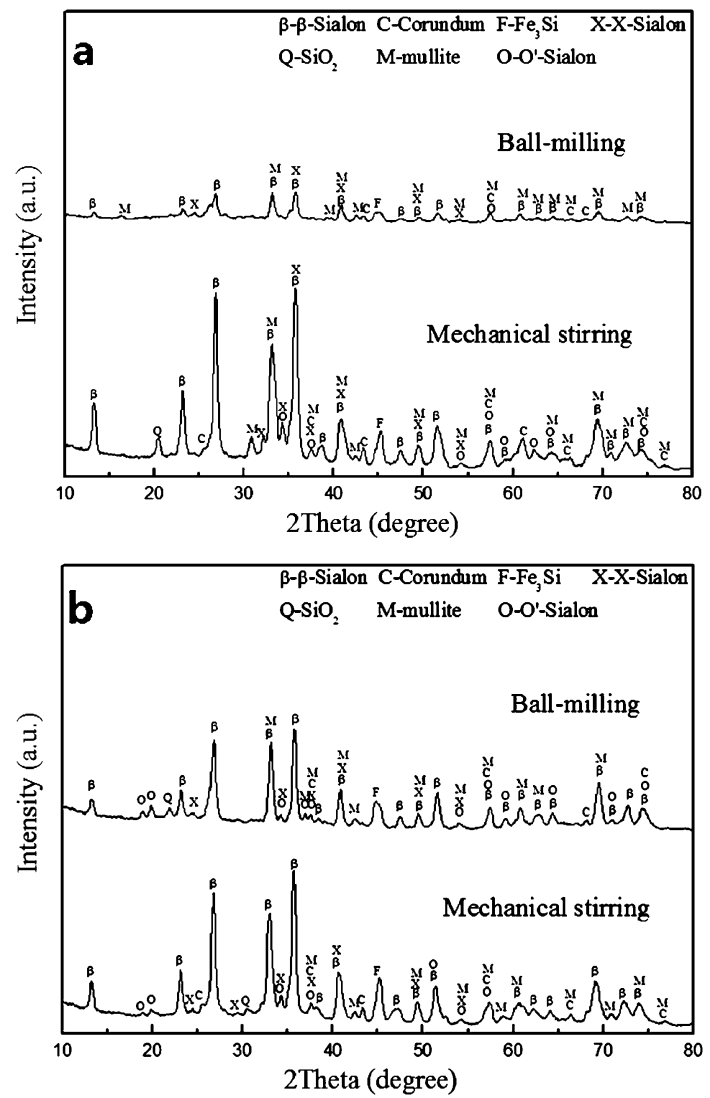

Fig. 4. XRD patterns of $\beta$-Sialon sample synthesized from fly ash samples mixed with lignite char (a) and graphite (b) by different mixing methods with $50 \%$ excess carbon.
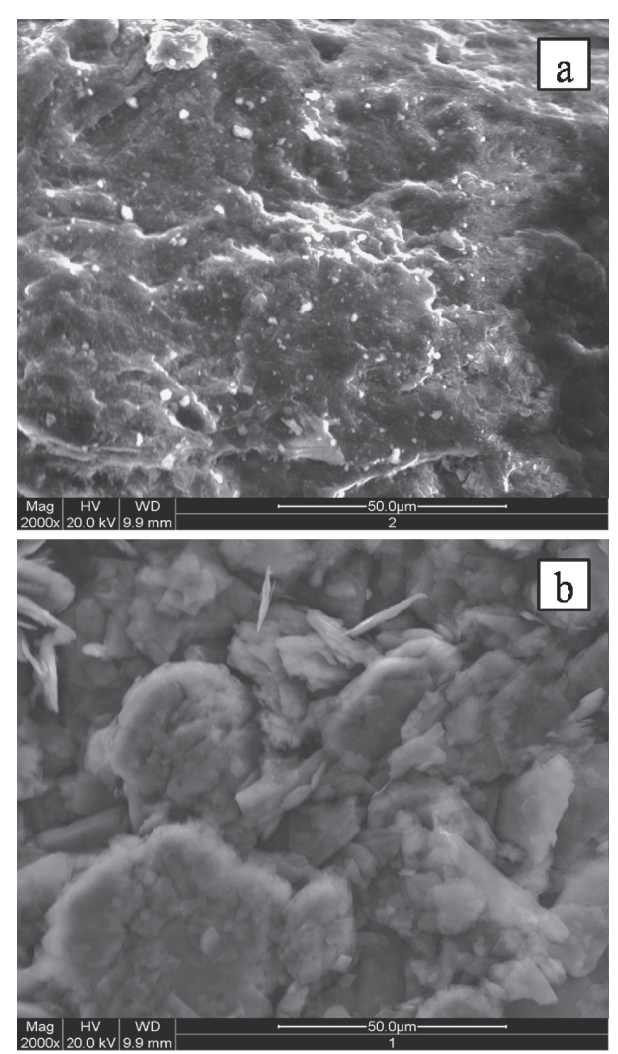

Fig. 5. SEM images of surface morphology of lignite char (a) and graphite (b) before the mixing operation. 
ash as an impurity, although magnetic separation has been carried out with fly ash samples before experiments, through which the majority of the iron impurities were removed from the fly ash. ${ }^{18)}$ The iron oxide impurity in samples may act as a promoting agent during the prepared process of $\beta$-Sialon phases. ${ }^{25)}$ This is due to its role in assisting the nitrogen molecule breakdown and reducing the melting point of fly ash. ${ }^{26), 27)}$

\subsubsection{Effect of carbon content}

Lignite chars and graphite with 10, 50, and 100\% excess carbon were added to fly ash by mechanical stirring, and the mixtures were sintered at $1420^{\circ} \mathrm{C}$ for $6 \mathrm{~h}$. The effects of excess carbon on the formation of $\beta$-Sialon are shown in Fig. 6. It can been seen that diffraction intensities of $\beta$-Sialon in samples with $50 \%$ excess carbon were stronger than that of the rest of the samples. For the samples with $10 \%$ excess carbon, the secondary
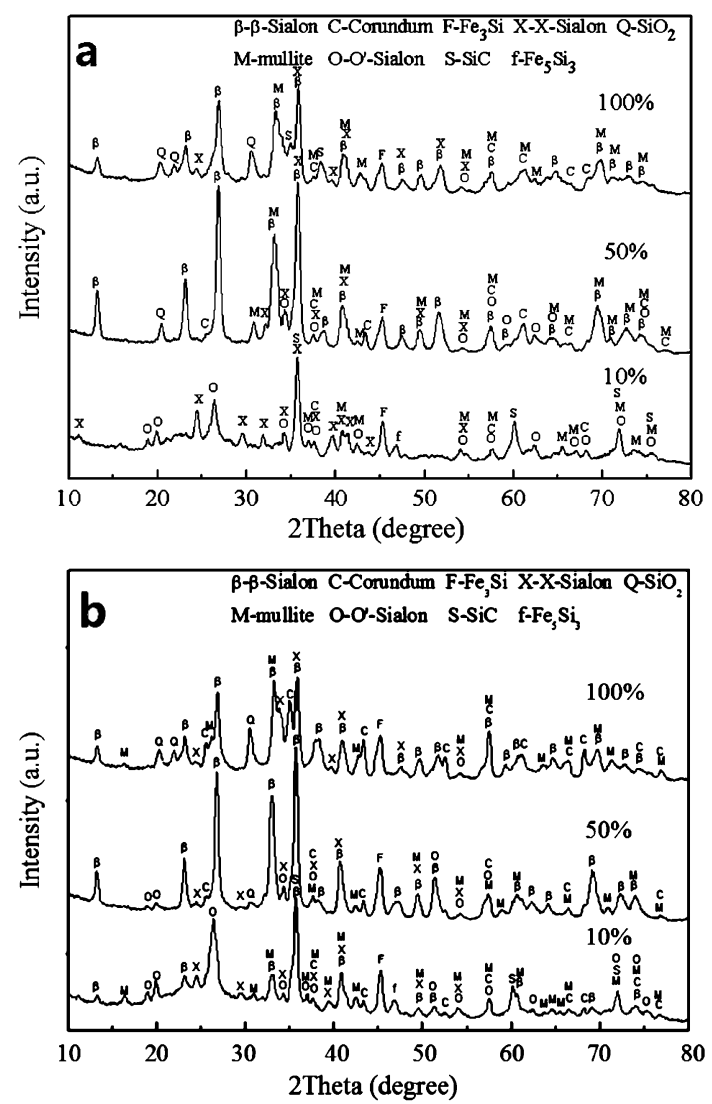

Fig. 6. XRD patterns of $\beta$-Sialon sample synthesized from fly ash samples mixed with lignite char (a) and graphite (b) by mechanical stirring with different excess carbon contents. phases (i.e., X-Sialon and O'-Sialon) were main products, and only a small amount of $\beta$-Sialon phase was found. With increasing carbon content these secondary phases decreased and $\beta$ Sialon phase increased rapidly. Especially, O'-Sialon in samples with $100 \%$ excess carbon almost disappeared. The evolution of these phases revealed that excess carbon has advantage to the preparation of $\beta$-Sialon phase from fly ash. Gilbert et al. ${ }^{4)}$ directly used fly ash with a carbon content as high as $28.46 \%$ to prepare $\beta$-Sialon. Qiu et al. ${ }^{12)}$ obtained the highest nitrogen content in the Sialon product by heating the mixture of fly ash and carbon black with carbon content of about $28 \mathrm{wt} \%$. However, excessive carbon content may negatively affect the CRN reaction. As shown in Fig. 7, carbon materials gradually covered the fly ash bed with increasing carbon content. When the excess carbon content reached to $100 \%$, a lot of fly ash particles were almost covered by the flaky-like carbon materials. The excessive carbon content leads to the thicker carbon-rich layer that forms outside the fly ash bed, which can impede the nitrogen gas penetration to the inner parts of the fly ash bed to drive the CRN reaction. ${ }^{28)}$ It is explanation for the decreased diffraction intensities of $\beta$-Sialon with increasing carbon content to $100 \%$.

From Fig. 6, silicon carbide ( $\mathrm{SiC}$ ), which is very often the first intermediate product, ${ }^{4}$ ) was observed in samples with $10 \%$ excess carbon content. The excess carbon increased the partial pressure of $\mathrm{CO}$, which enhanced the formation of $\mathrm{SiC}$ according to reaction (2). ${ }^{8), 12), 28)}$ Qiu et al. ${ }^{12)}$ observed the increase of SiC under the carbon-rich condition during the first $1 \mathrm{~h}$ at $1400^{\circ} \mathrm{C}$. Mitomo et al. ${ }^{29)}$ reported the formation of $\beta-\mathrm{SiC}$ as a minor product at temperatures of $1550-1600^{\circ} \mathrm{C}$ with high carbon addition to the reactants. Qiu et al. ${ }^{28)}$ also observed the formation of $\beta$-SiC, 15R-AIN in similar situation. As shown in Fig. 6, the amount of $\beta$-Sialon phase increased and SiC phase almost disappeared with increasing carbon content, implying that $\mathrm{SiC}$ phase was completely consumed by $\mathrm{CRN}$ reaction with mullite and generated $\beta$ Sialon phases [reaction (3)]. Similar results were also reported by Xu et al. ${ }^{8)}$ and Mazzoni et al. ${ }^{30)}$ For samples adding $100 \%$ excess carbon, small amount of $\mathrm{SiC}$ phase appeared in samples mixed with lignite chars, while not in those mixed with graphite. This is possibly due to the greater combustion reactivity of lignite chars compared to graphite, as shown in Fig. 8.

$$
\begin{aligned}
& \mathrm{SiO}_{2}(\mathrm{~s})+\mathrm{C}(\mathrm{s})=\mathrm{SiC}(\mathrm{s})+2 \mathrm{CO}(\mathrm{g}) \\
& 3 \mathrm{Al}_{2} \mathrm{O}_{3} \cdot 2 \mathrm{SiO}_{2}(\mathrm{~s})+4 \mathrm{SiC}(\mathrm{s})+3 \mathrm{C}(\mathrm{s})+5 \mathrm{~N}_{2}(\mathrm{~g}) \\
& \quad=2 \mathrm{Si}_{3} \mathrm{Al}_{3} \mathrm{O}_{3} \mathrm{~N}_{5}(\mathrm{~s})+7 \mathrm{CO}(\mathrm{g})
\end{aligned}
$$

\subsubsection{Effect of reaction temperature}

The samples mixed with lignite chars or graphite were sintered at 1400,1420 and $1450^{\circ} \mathrm{C}$ for $6 \mathrm{~h}$ and the results are shown in Fig. 9. It can be seen from Fig. 9(a) that $\beta$-Sialon phase and the secondary phases (i.e., X-Sialon and O'-Sialon) were the main

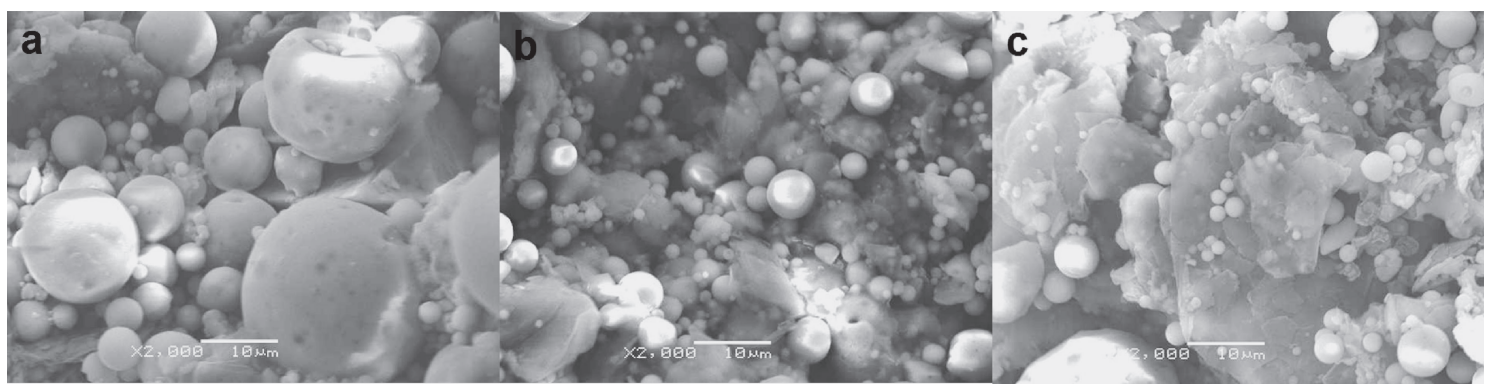

Fig. 7. SEM images of the morphology of mixed samples mixed with graphite at different excess carbon contents. (a) $10 \%$, (b) $50 \%$ and (c) $100 \%$. 


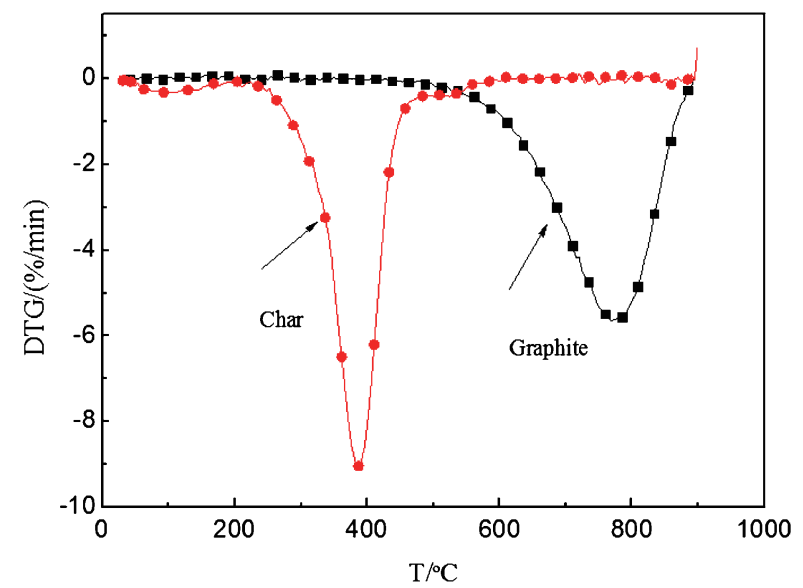

Fig. 8. DTG curves of char and graphite during combustion on TGA
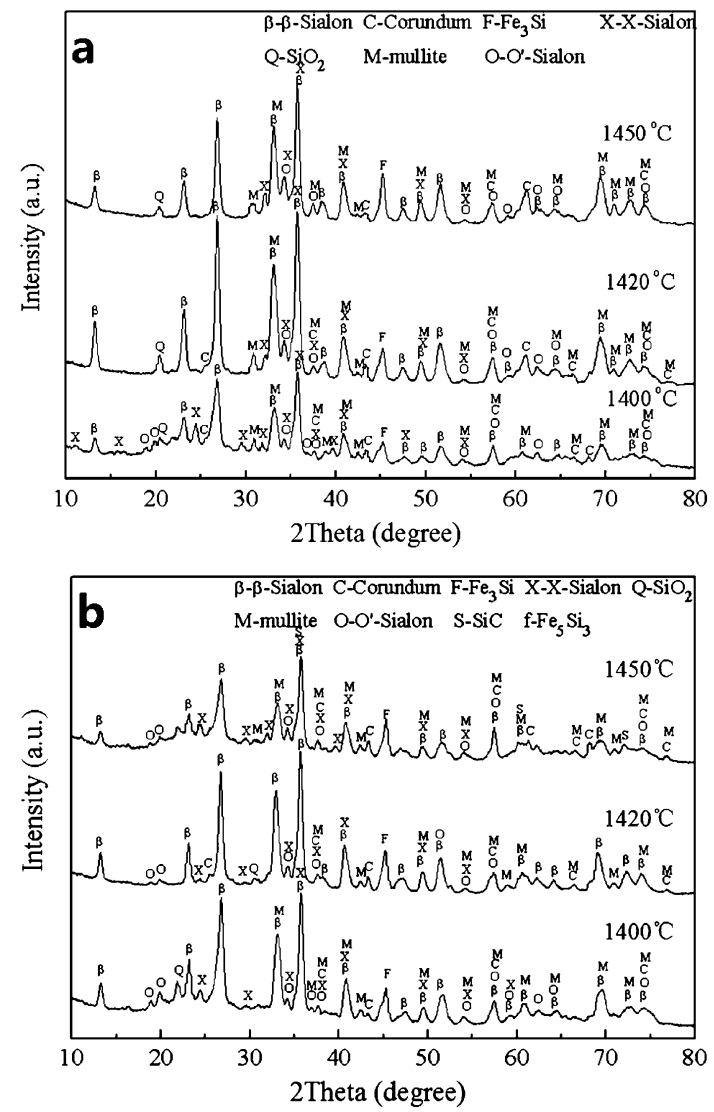

Fig. 9. XRD patterns of $\beta$-Sialon samples synthesized at different temperatures using fly ash samples mixed with lignite char (a) and graphite (b) by mechanical stirring with 50\% excess carbon.

products in samples sintered at $1400^{\circ} \mathrm{C}$. With increasing reaction temperature to $1420^{\circ} \mathrm{C}$ the $\beta$-Sialon phase increased and the secondary phases decreased rapidly, indicating that higher reaction temperature can promote the formation of $\beta$-Sialon phase. This result is consistent with those reported in the literature. ${ }^{4), 8), 12), 13), 18)}$ However Fig. 9(b) clearly shows that $\beta$-Sialon phase and the secondary phases remained relatively unchanged. The differences in the evolution of these phases were probably due to two reasons. The first was the difference in carbon materials added into the fly ash. The samples mixed with lignite
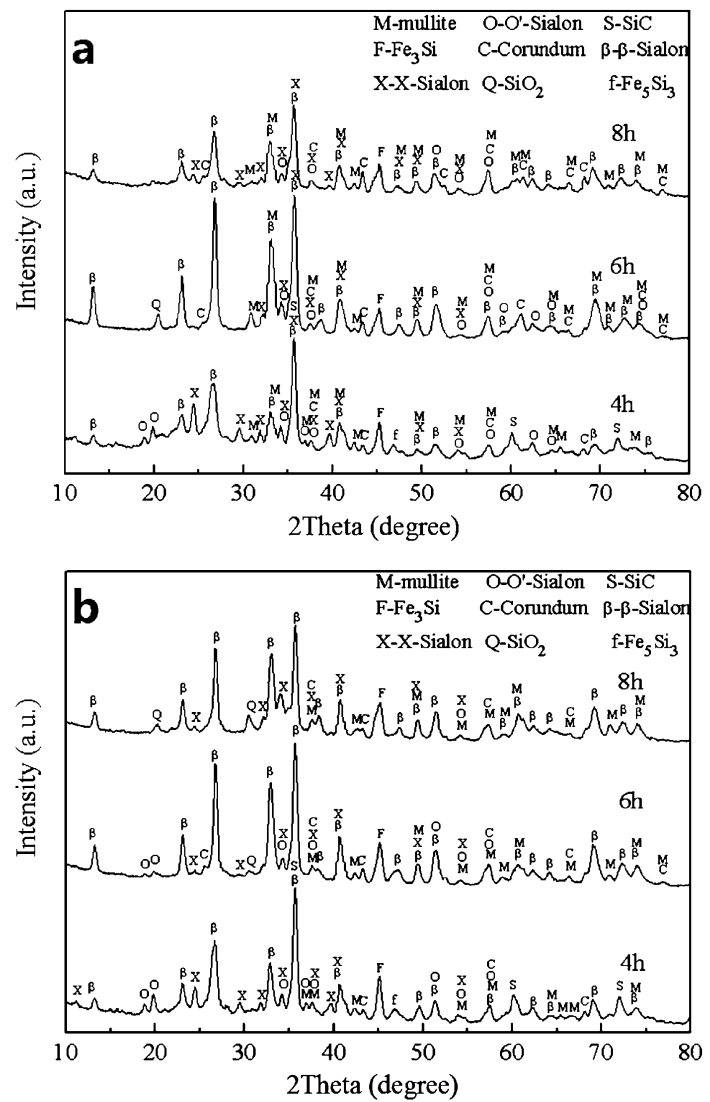

Fig. 10. XRD patterns of $\beta$-Sialon samples synthesised at $1420^{\circ} \mathrm{C}$ for different times from fly ash samples mixed with by lignite char (a) and graphite (b) by mechanical stirring with $50 \%$ excess carbon.

chars were more sensitive to the variation of reaction temperature than ones mixed with graphite, which was attributed to the structures of chars from low-temperature pyrolysis of lignite. Because of the higher porosity of chars, the nitrogen gas diffusivity into the char structure increases, resulting in higher reactivity. ${ }^{22), 31), 32)}$ Some impurities (e.g. $\mathrm{Fe}, \mathrm{Mg}, \mathrm{Ca}$ ) in lignite chars may promote the kinetics of the nitridation, although the mechanism of the nitridation reaction has not yet been fully understood and remains a subject for further studies. ${ }^{5), 12), 24)}$ The second reason is the smaller range of reaction temperature. Qiu et al. ${ }^{12)}$ used fly ash and carbon black and produced almost pure $\beta$-Sialon powder at lower temperature (i.e. $1300^{\circ} \mathrm{C}$ ).

When the reaction temperature was $1450^{\circ} \mathrm{C}$, the $\beta$-Sialon phase slightly decreased and the secondary phases still remained relatively unchanged compared to that at $1420^{\circ} \mathrm{C}$, shown in Fig. 9. For the samples mixed with graphite [Fig. 9(b)], the evolution of these phases was more significant. A small amount of $\mathrm{SiC}$ and corundum phases also appeared. It implied that the $\beta$-Sialon phase probably further decomposed to $\mathrm{Al}_{2} \mathrm{O}_{3}$ and $\mathrm{SiC}{ }^{33), 34)}$ Thus, further increase in the reaction temperature can lead to the conversion of $\beta$-Sialon phase. ${ }^{12), 18)}$ Therefore, there appears to be an optimum reaction temperature for the production of $\beta$-Sialon.

\subsubsection{Effect of sintering time}

The sample mixed with lignite chars or graphite was sintered at $1420^{\circ} \mathrm{C}$ for 4,6 , and $8 \mathrm{~h}$. The results are shown in Fig. 10 . Appearance of $\beta$-Sialon phase started to be obvious at the sintering time of $4 \mathrm{~h}$ with some secondary phases including XSialon, O'-Sialon and $\mathrm{SiC}$ co-existed. With increasing sintering 
time, the XRD intensity of $\beta$-Sialon phase increased and that of the secondary phases progressively decreased, indicating the conversion of the secondary phases to $\beta$-Sialon phase. ${ }^{7), 11), 13)}$ $\mathrm{Al}_{2} \mathrm{O}_{3}$ and $\mathrm{SiO}_{2}$ in the sample reacted originally with carbon and nitrogen to form X-Sialon and O'-Sialon phases [reactions (4)(5)] which were further nitridized to produce $\beta$-Sialon phases [reactions (6)-(7)]. The disappearance of $\mathrm{SiC}$ phase after $4 \mathrm{~h}$ revealed that this phase was an intermediate product in the carbothermal synthesis of $\beta$-Sialon, which is in agreement with the results from Fig. 6 .

$$
\begin{aligned}
& 3 \mathrm{Al}_{2} \mathrm{O}_{3}(\mathrm{~s})+3 \mathrm{SiO}_{2}(\mathrm{~s})+3 \mathrm{C}(\mathrm{s})+\mathrm{N}_{2}(\mathrm{~g}) \\
& \quad=\mathrm{Si}_{3} \mathrm{Al}_{6} \mathrm{O}_{12} \mathrm{~N}_{2}(\mathrm{~s})+3 \mathrm{CO}(\mathrm{g}) \\
& \quad 0.17 \mathrm{Al}_{2} \mathrm{O}_{3}(\mathrm{~s})+3.66 \mathrm{SiO}_{2}(\mathrm{~s})+5.49 \mathrm{C}(\mathrm{s})+1.83 \mathrm{~N}_{2}(\mathrm{~g}) \\
& \quad=2 \mathrm{Si}_{1.83} \mathrm{Al}_{0.17} \mathrm{O}_{1.17} \mathrm{~N}_{1.83}(\mathrm{~s})+5.49 \mathrm{CO}(\mathrm{g}) \\
& \quad \mathrm{Si}_{3} \mathrm{Al}_{6} \mathrm{O}_{12} \mathrm{~N}_{2}(\mathrm{~s})+3 \mathrm{SiO}_{2}(\mathrm{~s})+12 \mathrm{C}(\mathrm{s})+4 \mathrm{~N}_{2}(\mathrm{~g}) \\
& \quad=2 \mathrm{Si}_{3} \mathrm{Al}_{3} \mathrm{O}_{3} \mathrm{~N}_{5}(\mathrm{~s})+12 \mathrm{CO}(\mathrm{g}) \\
& 3 \mathrm{Si}_{1.83} \mathrm{Al}_{0.17} \mathrm{O}_{1.17} \mathrm{~N}_{1.83}(\mathrm{~s})+2.49 \mathrm{Al}_{2} \mathrm{O}_{3}(\mathrm{~s})+3 \mathrm{C}(\mathrm{s})+1.83 \mathrm{~N}_{2}(\mathrm{~g}) \\
& \quad=1.83 \mathrm{Si}_{3} \mathrm{Al}_{3} \mathrm{O}_{3} \mathrm{~N}_{5}(\mathrm{~s})+3 \mathrm{CO}(\mathrm{g})
\end{aligned}
$$

The diffraction intensities of $\beta$-Sialon phase begun to decrease after $6 \mathrm{~h}$, implying that decomposition or conversion of this phase had taken place. Similar trend during reaction process was observed by Qiu et al. ${ }^{12)}$ and Yoshimatsu et al. ${ }^{35}$ ) The phenomenon was more obvious for the samples mixed with lignite chars compared to that with graphite. This is due to the higher reactivity of the chars itself and the catalytic effects of some impurities in chars accelerating the reactions to form other phases. ${ }^{19), 36)}$

\subsection{Formation of $\beta$-Sialon whiskers}

The optimum experimental conditions for the $\beta$-Sialon synthesis in our experiments was found to be that: 1) for preparation, fly ash samples were mixed with reductants with $50 \%$ excess carbon content by mechanical stirring and, 2) $\mathrm{CRN}$ reactions at $1420^{\circ} \mathrm{C}$ for $6 \mathrm{~h}$. Figure 11 shows the microstructure of the samples synthesised under the optimum conditions. It can be seen from Fig. 11(a) that some rod-like $\beta$-Sialon whiskers with high aspect ratio were formed. There were some nodules on the whiskers by further carefully observing the image. This feature is more significant in Fig. 11(b). Moreover, some $\beta$-Sialon nanostructure whiskers were also found from Fig. 11(b). These whiskers with the diameter between 100 and $500 \mathrm{~nm}$ were better developed than ones in Fig. 11(a). Possible explanation for the formation of the thicker rod-like whiskers in samples adding lignite chars is that the higher reactivity of low-temperature chars promoted chemical vapour deposition ${ }^{37)}$ during the process of whisker growth.

The intermediate morphology during the growth process of $\beta$-Sialon whiskers is shown in Fig. 12. As shown in Fig. 12(a), the surfaces of the samples started to melt and the melted droplets with the impurities (e.g., Fe) appeared under the influence of surface tension. ${ }^{5), 37), 38)}$ Some liquid droplets were linked accompanying by solution of gaseous products (e.g., $\mathrm{SiO}, \mathrm{Al}_{2} \mathrm{O}$ ), ${ }^{5), 39)}$ super saturation of the liquid, ${ }^{40)}$ and precipitation of $\beta$-Sialon at the solid-liquid interface. ${ }^{37)}$ When the samples were sintered for $2 \mathrm{~h}$, bead-like whiskers became more visible as the predominant crystal morphology [See Fig. 12(b)]. With the increasing sintering time, the liquid phases were gradually exhausted by continuous vaporization and reactions, and rod-like $\beta$-Sialon whiskers without nodules were progressively formed [See Figs. 12(c) and 11(a)]. The similar growth process of $\beta$-Sialon whiskers for the samples adding graphite can also be observed, although the results were not exhibited in this study.
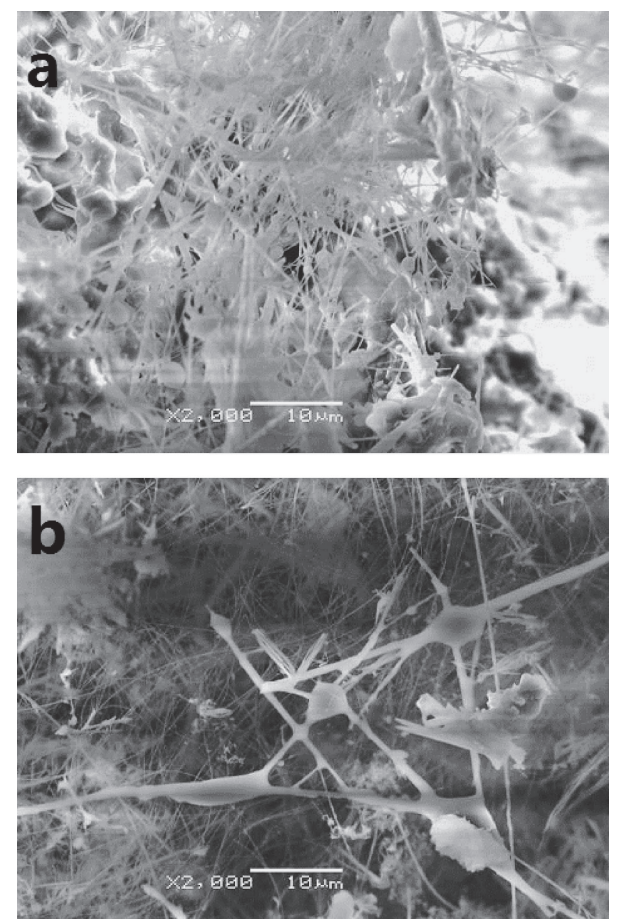

Fig. 11. SEM images of $\beta$-Sialon whiskers synthesised from fly ash mixed with lignite chars (a) and graphite (b).

The formation of $\beta$-Sialon whiskers was elucidated often through the vapor-liquid-solid (VLS) mechanism in the literature. ${ }^{40), 41)}$ However, it was found that the growth process was different from the conventional VLS mechanism. A chain of droplets on a whisker were formed to participate in the transportation of chemical components under present experiments. There were two explanations for the whisker formation. 1) The impurities such as Fe may have acted as a catalyst (or solutionforming agent). ${ }^{42)}$ 2) The flow pattern of $\mathrm{N}_{2}$ gas in the vertical reactor has led to the change in the growth mechanism. Yuan and $\mathrm{Pan}^{43)}$ reported that the morphologies of TiC whiskers depended on the variation of the axial effective concentration of vapor phase along the vertical reaction tube. Under the present experimental conditions, nitrogen gas was introduced to the bottom of the reactor by a gas inlet tube, and then guided through the samples from bottom to top. The gas at inlet had a high concentration, promoting the $\mathrm{CRN}$ reaction. A large amount of gaseous products (e.g., $\mathrm{SiO}, \mathrm{Al}_{2} \mathrm{O}$ ) were continually dissolved into the fresh liquid droplets. The diffusion of resultant carbon monoxide gases accompanying by the nitrogen flow also accelerated precipitation of $\beta$-Sialon at the solid-liquid interface. ${ }^{42), 44)}$ Thus, these droplets were linked and the bead-like whiskers was formed as a result.

\section{Conclusions}

The formation of $\beta$-Sialon was strongly influenced by the carbon source materials, mixing methods, excess carbon ratio, reaction temperature and time under conditions studied. The fly ash mixed with chars resulted in a $\beta$-Sialon sample with stronger XRD diffraction intensities which was attributed to a greater concentration of surface active sites and macropores in chars. Silicon carbide $(\mathrm{SiC})$ appeared and then disappeared with increasing carbon content, indicating the mechanism of $\beta$-Sialon generation through the reaction between $\mathrm{SiC}$ and mullite. With increasing reaction temperature $\beta$-Sialon phase increased and decreased 

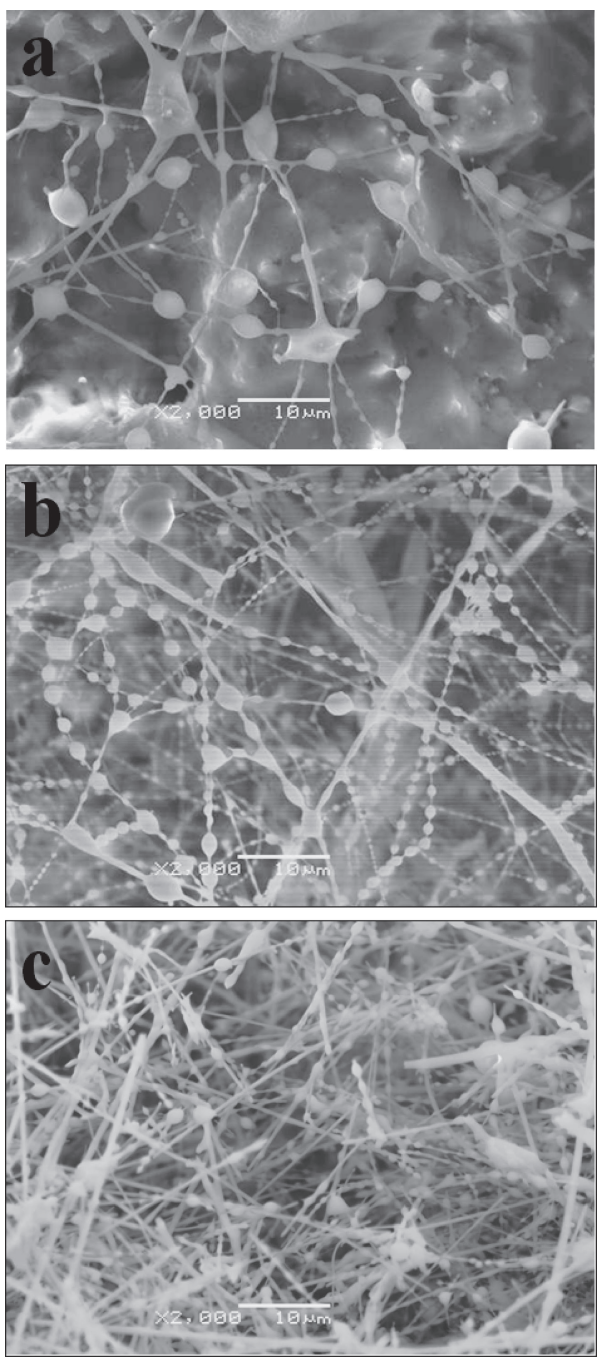

Fig. 12. SEM images of $\beta$-Sialon whiskers synthesised from fly ash mixed with lignite chars at $1420^{\circ} \mathrm{C}$ for (a) $1 \mathrm{~h}$, (b) $2 \mathrm{~h}$ and (c) $4 \mathrm{~h}$. (by mechanical stirring and with $50 \%$ excess carbon.)

thereafter. The formation of $\beta$-Sialon in the fly ash samples mixed with chars was more sensitive to the reaction temperature than that with graphite. $\beta$-Sialon phase increased gradually with increasing sintering time until $6 \mathrm{~h}$ and declined thereafter. Mechanical stirring mixing method was favored for the production of $\beta$-Sialon.

The optimal production conditions was found to be that fly ash samples mixed with reductant with $50 \%$ excess carbon through mechanical stirring for the preparation, and $1420^{\circ} \mathrm{C}$ for $6 \mathrm{~h}$ for the CRN reaction. Rod-like $\beta$-Sialon whiskers with high aspect ratio were formed while bead-like $\beta$-Sialon whiskers were also observed as intermediate product. The growth process of whiskers was different from the conventional VLS mechanism.

Acknowledgements This study was supported by the Natural Science Foundation of China (51404154 and 21476100).

\section{References}

1) K. H. Jack, J. Mater. Sci., 11, 1135-1158 (1976).

2) Y. Oyama and O. Kamigaito, Jpn. J. Appl. Phys., 10, 16371642 (1971).

3) T. Ekstrom and M. Nygren, J. Am. Ceram. Soc., 75, 259-276
(1992).

4) J. E. Gilbert and A. Mosset, Mater. Res. Bull., 33, 117-123 (1998).

5) J. K. Yu, S. Ueno, K. Hiragushi, S. W. Zhang and A. Yamaguchi, J. Ceram. Soc. Japan, 105, 821-823 (1997).

6) F. J. Li, T. Wakihara, J. Tatami, K. Komeya and T. Meguro, J. Eur. Ceram. Soc., 27, 2535-2540 (2007).

7) F. J. Li, T. Wakihara, J. Tatami, K. Komeya, T. Meguro and K. J. D. Mackenzie, J. Am. Ceram. Soc., 90, 1541-1544 (2007).

8) L. H. Xu, F. Lian, H. Zhang, Y. B. Bi, K. Cheng and Y. B. Qian, Mater. Des., 27, 595-600 (2006).

9) H. J. Zhang, B. Han and Z. J. Liu, Mater. Res. Bull., 41, 16811689 (2006).

10) X. Y. Luo, J. L. Sun, C. J. Deng and Y. R. Hong, J. Mater. Sci. Technol., 19, 93-96 (2003).

11) J. E. Gilbert and A. Mosset, Mater. Res. Bull., 32, 1441-1448 (1997).

12) Q. Qiu, V. Hlavacek and S. Prochazka, Ind. Eng. Chem. Res., 44, 2469-2476 (2005).

13) B. Y. Ma, Y. Li, C. Yan and Y. S. Ding, Trans. Nonferrous. Met. Soc. China, 22, 129-133 (2012).

14) N. Shigemoto, H. Hayashi and K. Miyaura, J. Mater. Sci., 28, 4781-4786 (1993).

15) S. Mu, B. G. Ma, G. D. Schutter, X. G. Li, Y. C. Wang and S. W. Jian, Construct. Build. Mater., 25, 617-622 (2011).

16) H. S. Choi, J. S. Roh and D. S. Suhr, Yoop Hakhoechi, 33, 871-876 (1996).

17) R. Metselaar, D. Exalto, T. Van Mol and H. T. Hintzen, Int Ceram. Monogr., 2, 1207-1213 (1996).

18) A. A. Kudyba-Jansen, H. T. Hintzen and R. Metselaar, Mater Res. Bull., 36, 1215-1230 (2001).

19) G. P. Shveikin and T. A. Timoshchuk, Inorg. Mater, 36, 891894 (2000).

20) J. T. Huang, M. H. Fang, Y. G. Liu and Z. H. Huang, Key Eng. Mater., 368-372, 910-912 (2008)

21) H. J. Wang and Y. L. Wang, J. Mater. Process. Technol., 117, 52-57 (2001).

22) F. R. Meng, J. L. Yu, A. Tahmasebi, Y. N. Han, H. Zhao and J. Lucas, Energy Fuels, 28, 275-284 (2014).

23) J. Mukerji and S. Bandyopadhyay, Indian J. Technol., 23, 227231 (1985).

24) F. K. Van Dijen, K. Metselaar and C. A. M. Siskens, J. Am. Ceram. Soc., 68, 16-19 (1985).

25) J. G. Lee and I. B. Cutler, Am. Ceram. Soc. Bull., 58, 869-871 (1979).

26) J. V. Milewski, F. D. Gac, J. J. Petrovic and S. R. Skaggs, J. Mater. Sci., 20, 1160-1166 (1985).

27) P. D. Ramesh and K. J. Rao, J. Am. Ceram. Soc., 78, 395-400 (1995).

28) J. Y. Qiu, J. Tatami, C. Zhang, K. Komeya, T. Meguro and Y. B. Cheng, J. Eur. Ceram. Soc., 22, 2989-2996 (2002).

29) M. Mitomo, M. Takeuchi and M. Ohmasa, Ceram. Int., 14, 4348 (1988)

30) A. D. Mazzoni, E. F. Aglietti and E. Pereira, Mater. Chem. Phys., 31, 325-331 (1992).

31) M. R. Khan, Fuel, 66, 1626-1634 (1987).

32) M. L. Shchipko and B. N. Kuznetsov, Fuel, 77, 527-532 (1988).

33) P. K. Panda, L. Mariappan and T. S. Kannan, Ceram. Int., 26, 455-461 (2000).

34) S. Bandopadhyay and J. Mukherjee, Ceram. Int., 18, 307-315 (1992).

35) H. Yoshimatsu, T. Yabuki and H. Mihashi, J. Ceram. Soc. Jpn. Int. Ed., 95, 544-548 (1987).

36) J. W. T. Van Rutten, R. A. Terpstra, J. C. T. Van der Heijde, H. T. Hintzen and R. Metselaar, J. Eur. Ceram. Soc., 15, 599604 (1995).

37) N. Ahlen, M. Johnsson, A. K. Larsson and B. Sundman, J. Eur. 
Ceram. Soc., 20, 2607-2618 (2000).

38) J. T. Huang, M. H. Fang, Z. H. Huang, Y. G. Liu, J. Z. Yang, S. F. Huang, Y. G. Xu, K. Chen, S. Yi and S. W. Zhang, Adv. Mater. Sci. Eng., 2014, 789867 (2014).

39) P. Dong, X. Wang, M. Zhang, M. Guo and S. Seetharaman, J. Nanomater, 2008, 282187 (2008).

40) R. S. Wagner and W. C. Ellis, Trans. Metall. Soc. AIME, 233, 1053-1064 (1965).
41) J. V. Milewski, F. D. Gac, J. J. Petrovic and S. R. Skaggs, J. Mater. Sci., 20, 1160-1166 (1985).

42) Q. Qiu and V. Hlavacek, Ind. Eng. Chem. Res., 44, 2477-2483 (2005).

43) Y. W. Yuan and J. S. Pan, J. Cryst. Growth, 193, 585-591 (1998).

44) Q. Qiu and V. Hlavacek, Ind. Eng. Chem. Res., 44, 7352-7358 (2005). 